\title{
Scientific Conceptions of Photosynthesis among Primary School Pupils and Student Teachers of Biology
}

Darja Skribe Dimec ${ }^{1}$ ANd Jelka Strgar ${ }^{\star 2}$

$\approx$ Photosynthesis is the most important biochemical process on Earth. Most living beings depend on it directly or indirectly. Knowledge about photosynthesis enables us to understand how the world functions as an ecosystem and how photosynthesis acts as a bridge between the non-living and living worlds. It is, therefore, understandable that photosynthesis is included in national curricula around the world. The practice unfortunately shows that students at all school levels mostly learn about photosynthesis by rote. Consequently, they have difficulties understanding this vital process. Research also shows many misconceptions in relation to photosynthesis among students of different ages. Based on these, the main aim of our study was to explore the scientific conceptions about photosynthesis held by primary school pupils and student teachers of biology. Data were collected using a questionnaire containing seven biology content questions. The sample consisted of 634 participants, 427 primary school pupils (aged 11-14), and 207 student teachers of biology (aged 20-23). We found that the populations of primary school pupils and student teachers of biology differ greatly concerning scientific conceptions of photosynthesis. The student teachers showed good and complex understanding of photosynthesis, while pupils showed some misconceptions (location of chlorophyll and photosynthesis in a plant, transformation of energy in photosynthesis). Analysis of the development of scientific conceptions about photosynthesis with age showed that there is very little progress among primary school pupils and none among biology student teachers. More involvement of student teachers of biology in practical work at primary schools during their study was suggested to make student teachers aware of, and better understand pupils' misconceptions.

Keywords: photosynthesis; biology; scientific conceptions; development; primary school; pupils; student teachers of biology

1 University of Ljubljana, Faculty of Education, Slovenia.

2 *Corresponding Author. University of Ljubljana, Biotechnical Faculty, Department of Biology, Slovenia; jelka.strgar@bf.uni-lj.si. 


\section{Znanstvena pojmovanja o fotosintezi pri učencih osnovne šole in bodočih učiteljih biologije}

Darja Skribe Dimec in Jelka Strgar

$\approx$ Fotosinteza je najpomembnejši biokemični proces na Zemlji. Od nje je posredno ali neposredno odvisna večina živih bitij na Zemlji. Poznavanje fotosinteze nam omogoča, da razumemo, kako deluje svet kot ekosistem ter kako fotosinteza deluje kot most med neživim in živim svetom. Zato je razumljivo, da je fotosinteza vključena v nacionalne učne načrte široko po svetu. Praksa žal kaže, da se učenci na vseh stopnjah izobraževanja fotosintezo večinoma učijo na pamet. Posledica tega je, da imajo težave pri razumevanju tega pomembnega procesa in da ne morejo uporabljati pridobljenega znanja. Raziskave kažejo tudi številna napačna pojmovanja, povezana s fotosintezo, ki jih imajo učenci različnih starosti. Izhajajoč iz tega, je bil glavni cilj naše študije raziskati znanstvena pojmovanja o fotosintezi med učenci osnovne šole in bodočimi učitelji biologije. Podatke smo zbrali z vprašalnikom, ki je vseboval 7 vprašanj. Vzorec je sestavljalo 634 sodelujočih, 427 učencev osnovne šole (starih 11-14 let) in 207 bodočih učiteljev biologije (20-23 let). Ugotovili smo, da se populaciji osnovnošolcev in bodočih učiteljev biologije med seboj zelo razlikujeta glede znanstvenih pojmovanj o fotosintezi. Bodoči učitelji biologije so pokazali zadovoljivo in kompleksno razumevanje znanstvenih pojmovanj o fotosintezi, medtem ko smo pri osnovnošolcih našli nekatera napačna pojmovanja (lega klorofila in poteka fotosinteze v rastlini, energetske pretvorbe pri fotosintezi). Analiza razvoja znanstvenih pojmovanj o fotosintezi glede na starost sodelujočih je pokazala, da je napredka na osnovnošolski stopnji zelo malo, med bodočimi učitelji biologije pa ga sploh ni. Predlagali smo večjo vključenost bodočih učiteljev biologije v praktično delo na osnovnih šolah med izobraževanjem na fakulteti, kar bi prispevalo k zavedanju in boljšemu razumevanju napačnih pojmovanj, ki jih imajo osnovnošolci.

Ključne besede: fotosinteza, biologija, znanstvena pojmovanja, razvoj, osnovna šola, učenci, bodoči učitelji biologije 


\section{Introduction}

\section{Knowledge and understanding of basic concepts related to photosynthesis}

If you asked biologists what the basic process on Earth is, they would most certainly respond 'photosynthesis'. Moreover, all non-biologists should respond in kind, since life on Earth depends primarily on this process. Most living organisms, including people, depend on photosynthesis. According to currently available data, the only exceptions are organisms that live in the deep ocean trenches and some other extreme environments; their mode of survival depends on chemosynthesis. As stated by Arnon (in Barker \& Carr, 1989a), photosynthesis eminently merits its distinction as the most important biochemical process on Earth. Marmaroti and Galanopoulou (2006) summarised the work of many researchers saying that knowledge of photosynthesis is imperative for a basic understanding of how the world functions as an ecosystem and how it acts as a bridge between the non-living and living worlds.

Consequently, it is understandable that learning about the process of photosynthesis is included in national school curricula. The international comparative study Trends in International Mathematics and Science Study (TIMSS) always includes items related to photosynthesis, which confirms the importance of this topic in the compulsory learning content of schools. In the national standards in the US, photosynthesis is included in the category 'matter cycling and energy transfer in natural ecosystems' (National Research Council, 1996). The latest science standards include photosynthesis within the disciplinary core ideas in the unit Organisation for Matter and Energy Flow in Organisms: 'Construct a scientific explanation based on evidence of the role of photosynthesis in the cycling of matter and flow of energy into and out of organisms' (MS-LS1-6. Next Generation Science Standards, 2013).

\section{Slovenian curriculum and biology education}

In Slovenia, per the school curriculum, pupils begin to familiarise themselves with the foundations of photosynthesis in the second grade of primary school, when aged seven years. The learning objective is to 'demonstrate that plants need air, water with mineral substances, and light in order to live' (Kolar, Krnel \& Velkavrh, 2011, 11). In the third grade, the general learning objective is that pupils learn 'that living organisms receive something from the environment (food, air, water) which is processed and transmitted into the 
environment'. The learning objective which refers only to the plants is that pupils 'are able to justify why plants more than other living organisms need light and water with mineral substances' (Kolar et al., 2011, p. 11). An objective in the fourth grade is only indirectly related to photosynthesis. Pupils have to classify living things into groups according to common characteristics (Vodopivec, $\mathrm{Pa}$ potnik, Gostinčar Blagotinšek, Skribe Dimec \& Balon, 2011, p. 17). The learning objectives related to photosynthesis of the curriculum for fifth grade are: 'The pupil is able to explain that plants from water and carbon dioxide produce food (organic matter) and excrete oxygen, and that, for this process (photosynthesis) sunlight as an energy source and chlorophyll are needed,' and 'the pupil is able to explain that the plants are producers and animals are consumers (of organic matter)' (Vodopivec et al., 2011, pp. 17-18). In sixth grade, the focus is on plant issues, and an entire chapter is devoted to photosynthesis (and cell respiration) in which the pupils' knowledge from previous classes is upgraded and expanded (Skvarč et al., 2011). In the seventh grade, there is an emphasis on learning about bacteria, fungi, and animals (Skvarč et al., 2011). In the final, ninth grade of primary school, the learning objective connected with photosynthesis has one objective ('[...] photosynthetic cyanobacteria have started to produce oxygen as a by-product of photosynthesis [...]' Vilhar et al., 2011, p. 17). We can conclude that photosynthesis is a process dealt with throughout the primary school curriculum, with the most emphasis in the sixth grade.

\section{Research studies about conceptions of photosynthesis}

Since the 1990s, when the constructivist theory of learning and teaching was implemented in education, many researchers have focused on students' conceptual development and cognitive processes. Deshmukh (2015) states that all these studies accepted that each student had a different cognitive structure because of their different abilities, backgrounds, attitudes, and experiences. Moreover, that this leads to intuitive understanding, which often means that something a person knows and believes does not match what is known to be scientifically correct. The constructivist theory established the term 'misconception' in pedagogy. Misconceptions (a.k.a. 'alternative conceptions', 'alternative frameworks', etc.) are a key issue of constructivism in science education, and a major theoretical perspective informing science teaching (Taber, 2011). Ozmen (in Deshmukh, 2015, p. 32) pointed out that 'a student's misconceptions before or after formal instruction have become a major concern among researchers in science education because they influence how students learn new scientific knowledge, play an essential role in subsequent learning, and become a hindrance in acquiring 
the correct body of knowledge.' Deshmukh (2015) refers to a variety of authors and summarises principal sources of students' science misconceptions, including textbooks and reference books, teachers, cultural beliefs and practices, life experiences, anthropomorphism, analogies, intuition, and language.

According to the widespread opinion about the importance of understanding the process of photosynthesis, it is not surprising that many researchers wanted to know what misconceptions students have in connection with this process. Driver et al. (1992) found that children around the world have similar problems in the understanding of complex processes, such as photosynthesis. The universal and very persistent intuitive conception, identified in all studies with subjects of all ages, is that plants get their food from their environment, especially from the soil (Leeds National Curriculum Science Support Project, 1992). Other common misconceptions identified are: roots are the organs of feeding; plants have multiple sources of food; carbon dioxide, water, and minerals are food for plants; sunlight, absorbed by plants, is food; and photosynthesis is something that plants do to the benefit of people and animals, particularly in relation to the exchange of gasses. A comprehensive examination of pupil understanding of photosynthesis was made by Marmaroti and Galanopoulou (2006). In their study, they examined six aspects of photosynthesis: physiology, photosynthesis and energy, photosynthesis as a chemical reaction, photosynthesis and plant feeding (autotrophy), photosynthesis and respiration, and photosynthesis and the function of the ecosystem. Their conclusions were that pupils do not understand energy transformations and the role of chlorophyll in photosynthesis; they do not see photosynthesis as a chemical reaction; they think plants receive food from their environment, and are confused about photosynthesis and respiration.

\section{Aims of the study and research questions}

The main aim of our study was to explore scientific conceptions about photosynthesis held by pupils and student teachers of biology (STB) because of the significance of photosynthesis for the functioning of ecosystems, and its role in the scientific literacy of all people. The aim was to analyse the quality of scientific conceptions about photosynthesis, the complexity of understanding of scientific conceptions about photosynthesis and how these conceptions about photosynthesis are changing with age.

According to our aims, we set the following three research questions:

1. What is the quality of scientific conceptions about photosynthesis held by pupils and student teachers of biology? 
2. How complex is the understanding of scientific conceptions about photosynthesis held by pupils and student teachers of biology?

3. How do scientific conceptions about photosynthesis held by pupils and student teachers of biology change with age?

\section{Methods}

In this study, we used a quantitative research approach. Data were gathered in 2014, 2015, and 2016, mostly as part of several graduate theses of students at the Faculty of Education of the University of Ljubljana; however, we used a different methodology of data analysis in the present study.

\section{Sample}

The study included 634 participants, of which 427 (67.4\%) were primary school pupils (PS) and 207 (32.6\%) students of the University of Ljubljana Faculty of Education, future two-subject teachers of biology and chemistry or home economics (STB), who will be teaching biology on the upper primary school level or in secondary schools. The proportion of females (47.8\%) among primary school pupils was roughly the same as the proportion of males $(52.2 \%)$. The teacher population in Slovenia is heavily dominated by females, which is also reflected in our sample, in which females represent 90.4\%. For STB, we included participants of the $2^{\text {nd }}, 3^{\text {rd }}, 4^{\text {th }}$, and $5^{\text {th }}$ years of study at the university. The sample of primary school pupils consisted of pupils in Grades 6 to 9 (Table 1).

Table 1. Distribution of participants according to years of education in each educational program (primary school pupils = PS, student teachers of biology = STB)

\begin{tabular}{lccc}
\hline \multirow{2}{*}{ Years of education } & Typical age & \multicolumn{2}{c}{ Participants } \\
\cline { 3 - 4 } & 11 & $\mathrm{~N}$ & $\mathrm{f}(\%)$ \\
\hline PS 6 & 12 & 103 & 24.1 \\
PS 7 & 13 & 111 & 26.0 \\
PS 8 & 14 & 98 & 26.9 \\
PS 9 & 20 & 77 & 23.0 \\
STB 2 & 21 & 28 & 37.2 \\
STB 3 & 22 & 69 & 13.5 \\
STB 4 & 23 & 33.3 \\
STB 5 & & 634 & 10.9 \\
\hline$\Sigma$ & & &
\end{tabular}




\section{Questionnaire}

Data were collected via a questionnaire containing three demographic questions (educational program, gender, and year of education) and seven multiple choice questions. Participants had to choose one answer from out of three to five. The same or similar questions were used in surveys by Domingos-Grilo, Reis-Grilo, Ruiz and Mellado (2012; question 'The main purpose of photosynthesis is to ...), Marmaroti and Galanopoulou (2006; questions 'Which pair of substances are the reactants in photosynthesis?', 'Which substances are products of photosynthesis?', 'Which part of the plant contains chlorophyll?', and 'In which part of the plant does photosynthesis take place?'), and Çepni, Taș and Köse (2006; 'Into what type of energy do plants transform sunlight into energy?'). We also added our own question: 'What type of energy do plants receive from the sun?'

With these questions, we evaluated the following four conceptions in connection with photosynthesis:

1. the function of photosynthesis (question 'The main purpose of photosynthesis is to ...),

2. the process of photosynthesis (questions 'Which pair of substances are the reactants in photosynthesis?', 'Which substances are products of photosynthesis?'),

3. photosynthesis and energy (questions 'What type of energy do plants receive from the sun?', 'Into what type of energy do plants transform sunlight into energy?'), and

4. chlorophyll (questions 'Which part of the plant contains chlorophyll?', 'In which part of the plant does photosynthesis take place?').

\section{Statistical analysis}

Basic descriptive statistics was performed. Since the data were not normally distributed, the non-parametric Mann-Whitney and Kruskal-Wallis tests were used to determine the statistical significance of differences between the responses of participants in various educational programs, years of education in this program, and gender. 


\section{Results}

In our study about the scientific conceptions of photosynthesis, we investigated primary school pupils and a population of STB. Mann-Whitney U tests show that to all seven questions concerning scientific conceptions primary school pupils gave statistically significantly different answers compared to STB (all $p<0.05$ ), which means that the two populations differed significantly in the scientific conceptions of photosynthesis.

\section{Quality of scientific conceptions about photosynthesis}

With the first question, we attempted to determine how pupils and STB understand the function of photosynthesis (Table 2). The most common response of pupils was that the main purpose of photosynthesis is the formation of oxygen (49\%), followed by the formation of glucose (38\%). Among STB, a sequence of those two responses is reversed. STB believe that the main purpose of photosynthesis is the formation of glucose $(63 \%)$ and $32 \%$ think that the formation of oxygen is the main purpose of photosynthesis. The remaining responses were chosen by less than $9 \%$ of the pupils and STB. Participants had to choose only one response from the four offered, and since during the process of photosynthesis two substances are made, the responses were combined (formation of glucose and formation of oxygen). We found that $87 \%$ of the pupils and $96 \%$ of the STB at least partially know what is made during photosynthesis. In their study, Domingos-Grilo et al. (2012) started from the fact that in the evolution the formation of glucose was the primary purpose of photosynthesis and oxygen was a by-product, so we used the formation of glucose as the correct answer.

Table 2. Percentage distribution of pupils' and student teachers' of biology (STB) responses to the question 'What is the main purpose of photosynthesis?'

\begin{tabular}{lcc}
\hline Response & Pupils (\%) & STB (\%) \\
\hline Consumption of carbon dioxide & 8.6 & 4.0 \\
Consumption of water & 4.7 & 0.5 \\
Formation of glucose & 37.7 & 63.2 \\
Formation of oxygen & 49.0 & 32.3 \\
\hline
\end{tabular}

The knowledge of the process of photosynthesis was measured with two questions (Table 3). With the first question, we wanted to verify whether the participants are aware of the reactants in photosynthesis, and with the second 
question whether they know the products of photosynthesis. When recognising reactants, the most common answer of all participants was the correct one (carbon dioxide and water): pupils (59\%) and STB (88\%). In the case of pupils, a remarkable proportion were represented by the incorrect replies 'oxygen and water' (22\%) and 'carbon dioxide and organic matter' (14\%).

Furthermore, in identifying the products of photosynthesis in both groups of participants, the most common answer was the correct one (glucose and oxygen): pupils (61\%) and STB (93\%). Quite a large proportion of pupils (23\%) chose the incorrect answer 'oxygen and water'. Each of the other wrong answers in both questions was chosen by less than $9 \%$ of the pupils and STB.

The proportion of pupils' correct answers of reactants and products is quite similar (59\% reactants, $61 \%$ products). The same also applies to the STB (reactants $88 \%$, products $93 \%$ ). Both groups of participants know the products of photosynthesis slightly better than they do the reactants.

Table 3. Percentage distribution of pupils' and student teachers of biology (STB) responses to the questions about the process of photosynthesis

\begin{tabular}{lcclcc}
\hline $\begin{array}{l}\text { Which pair of substances are the } \\
\text { reactants in photosynthesis? }\end{array}$ & $\begin{array}{c}\text { Pupils } \\
(\%)\end{array}$ & $\begin{array}{c}\text { STB } \\
(\%)\end{array}$ & $\begin{array}{l}\text { Which substances are } \\
\text { products of photosynthesis? }\end{array}$ & $\begin{array}{c}\text { Pupils } \\
(\%)\end{array}$ & $\begin{array}{l}\text { STB } \\
(\%)\end{array}$ \\
\hline Oxygen and organic matter & 5.6 & 1.0 & Glucose and oxygen & 61.3 & 92.7 \\
Oxygen and water & 21.9 & 2.9 & Oxygen and water & 22.7 & 3.9 \\
Carbon dioxide and organic matter & 14.0 & 7.8 & Carbon dioxide and glucose & 9.4 & 3.4 \\
Carbon dioxide and water & 58.5 & 88.2 & Carbon dioxide and water & 6.7 & 0.0 \\
\hline
\end{tabular}

To understand the events related to energy during the process of photosynthesis, we used two questions (Table 4). The purpose of the first question was to determine the form of the energy that plants obtain from the sun. The second question asked about into what type of energy plants transform sunlight energy. The dominant response in both the pupils and STB was that the energy that plants get from the sun is in the form of light energy (pupils $74 \%$, STB 89\%). In addition, pupils frequently chose the wrong answer, i.e. that the plants receive heat from the sun $(23 \%)$. The fact that plants receive light energy from the sun was known by most of the pupils and STB. The results showed that almost a quarter of pupils have the misconception that plants receive heat from the sun.

Pupils in approximately the same proportion believe that plants transform sunlight energy into chemical energy (35\%) or heat $(27 \%)$ or light energy $(24 \%)$ (Table 4$)$. A large majority of STB (89\%) thinks that sunlight energy is 
transformed into chemical energy during the photosynthesis. The results show that understanding of the energy transformation during the photosynthesis is rather vague among the primary school pupils, because they selected different types of energy. However, there is very little such incorrect assessment on the part of STB. Each of the other wrong answers in both questions was chosen by less than $9 \%$ of the pupils and STB.

Table 4. Percentage distribution of pupils' and student teachers of biology (STB) responses to the questions about photosynthesis and energy

\begin{tabular}{|c|c|c|c|c|c|}
\hline $\begin{array}{l}\text { What type of energy do plants } \\
\text { receive from the sun? }\end{array}$ & $\begin{array}{c}\text { Pupils } \\
\text { (\%) }\end{array}$ & $\begin{array}{l}\text { STB } \\
(\%)\end{array}$ & $\begin{array}{l}\text { Into what type of energy do } \\
\text { plants transform sunlight energy? }\end{array}$ & $\begin{array}{l}\text { Pupils } \\
\text { (\%) }\end{array}$ & $\begin{array}{l}\text { STB } \\
(\%)\end{array}$ \\
\hline Chemical energy & 3.4 & 6.3 & Electricity & 5.1 & 0.5 \\
\hline Light energy & 73.5 & 88.9 & Physical energy/Movement & 8.3 & 0.5 \\
\hline \multirow[t]{3}{*}{ Heat } & 23.1 & 4.8 & Chemical energy & 35.1 & 88.6 \\
\hline & & & Light energy & 24.2 & 3.0 \\
\hline & & & Heat & 27.3 & 7.4 \\
\hline
\end{tabular}

Next, we investigated whether participants know that photosynthesis takes place only where there is chlorophyll. First, we asked them whether they know in which parts of the plants that photosynthesis takes place, and second, whether they know in which parts of the plants there is chlorophyll (Table 5). For pupils, we found that a similar proportion believes that photosynthesis takes place 'in the leaves' (44\%) or 'in the green parts of plants' $(40 \%)$; $11 \%$ of pupils believe that photosynthesis takes place 'in the whole plant'. Most of STB replied that photosynthesis takes place 'in the green parts of plants' (88\%); $11 \%$ reported that it is carried out 'in the leaves.'

On the question of where the chlorophyll is, half the pupils (50\%) responded that the chlorophyll is 'in the green parts of plants', $33 \%$ answered 'in the leaves', and $12 \%$ said that it is 'in the roots' (Table 5). The predominant response among STB is that chlorophyll is 'in the green parts of plants' (93\%), only a few STB answered that it is 'in the leaves' (7\%). Approximately $10 \%$ of the pupils and $5 \%$ of the STB knew better in which part of the plant chlorophyll is than they knew where photosynthesis takes place. Each of the remaining responses in both questions was chosen by less than $6 \%$ of the pupils and STB. 
Table 5. Percentage distribution of pupils' and student teachers of biology (STB) responses to the questions about chlorophyll

\begin{tabular}{lcclcc}
\hline $\begin{array}{l}\text { In which part of the plant does } \\
\text { photosynthesis take place? }\end{array}$ & $\begin{array}{c}\text { Pupils } \\
(\%)\end{array}$ & $\begin{array}{l}\text { STB } \\
(\%)\end{array}$ & $\begin{array}{l}\text { Which part of the plant } \\
\text { contains chlorophyll? }\end{array}$ & $\begin{array}{c}\text { Pupils } \\
(\%)\end{array}$ & $\begin{array}{l}\text { STB } \\
(\%)\end{array}$ \\
\hline In the whole plant & 11.3 & 1.0 & Whole plant & 5.1 & 0.0 \\
In the roots & 2.4 & 0.0 & Roots & 12.4 & 0.0 \\
In the leaves & 43.9 & 11.0 & Leaves & 32.7 & 7.4 \\
In the stem & 2.7 & 0.0 & Green parts of the plant & 49.7 & 92.6 \\
In the green parts of the plant & 39.8 & 88.0 & & & \\
\hline
\end{tabular}

\section{Complexity of scientific conceptions about photosynthesis}

We explored the complexity of the scientific conceptions of photosynthesis by cross-analysing complementary or logically-related questions. Two questions were related to the process of photosynthesis, two to energy in photosynthesis, and two to chlorophyll.

In order to determine the complexity of understanding the process of photosynthesis, we cross-analysed responses of pupils and STB to the questions 'Which pair of substances are the reactants in photosynthesis?' and 'Which substances are products of photosynthesis?' (Table 6). We found that among pupils and STB the predominant combination was the correct one: the reactants in photosynthesis are carbon dioxide and water, and the products are glucose and oxygen (pupils 41\%, STB 84\%). Pupils also chose a large proportion of various false combinations. Twelve per cent of pupils chose water instead of glucose as a product of photosynthesis. Nine per cent of the pupils chose the correct products, but incorrect reactants (instead of water they picked organic matter). Eight per cent of the pupils chose a surprising combination in which the reactants are the same as the products. A further eight per cent of the pupils who chose the correct products and false reactants (instead of carbon dioxide water was chosen). 
Table 6. Cross-analysis of pupils' and student teachers of biology (STB) responses to determine the complexity of understanding the process of photosynthesis

\begin{tabular}{lcc}
\hline Response & $\begin{array}{c}\text { Pupils } \\
\text { (\%) }\end{array}$ & $\begin{array}{c}\text { STB } \\
\text { (\%) }\end{array}$ \\
\hline Reactants are oxygen and water, and products are glucose in oxygen & 7.9 & 2.0 \\
Reactants are oxygen and water, and products are oxygen and water & 8.4 & 0.0 \\
Reactants are carbon dioxide and organic matter, and products are glucose in oxygen & 9.4 & 6.4 \\
Reactants are carbon dioxide and water, and products are glucose in oxygen & 41.2 & 83.7 \\
Reactants are carbon dioxide and water, and products are oxygen and water & 11.5 & 2.5 \\
Reactants are carbon dioxide and water, and products are carbon dioxide and glucose & 3.7 & 2.0 \\
\hline
\end{tabular}

We also explored the complexity of understanding the connection between photosynthesis and chlorophyll. For this purpose, we cross-analysed responses of pupils and STB to the questions 'Which part of the plant contains chlorophyll?' and 'In which part of the plant does photosynthesis take place?' (Table 7). The most frequent response in both groups was the correct combination: 'Chlorophyll is in the green parts of the plant, and photosynthesis takes place in the green parts of the plant' (pupils 28\%, STB 84\%). Many pupils answered that chlorophyll is in the leaves $(18 \%)$ or in the green parts of the plant $(17 \%)$, or that photosynthesis takes place in the leaves $(36 \%)$. Ten percent of pupils associated photosynthesis with all green parts of plants, and chlorophyll only with leaves. Even some STB (8\%) responded that photosynthesis takes place in leaves, while chlorophyll is in the green parts of the plant.

Table 7. Cross-analysis of pupils' and student teachers of biology (STB) responses to explore the complexity of understanding the connection between photosynthesis and chlorophyll

\begin{tabular}{lll}
\hline Response & $\begin{array}{c}\text { Pupils } \\
\text { (\%) }\end{array}$ & $\begin{array}{c}\text { STB } \\
\text { (\%) }\end{array}$ \\
\hline Chlorophyll is in the leaves, and photosynthesis takes place in the whole plant & 4.1 & 0.0 \\
Chlorophyll is in the roots, and photosynthesis takes place in the leaves & 4.9 & 0.0 \\
Chlorophyll is in the leaves, and photosynthesis takes place in the leaves & 18.3 & 3.5 \\
Chlorophyll is in the green parts of the plant, and photosynthesis takes place in the leaves & 17.3 & 7.5 \\
Chlorophyll is in the leaves, and photosynthesis takes place in the green parts of the plant & 9.8 & 3.5 \\
$\begin{array}{l}\text { Chlorophyll is in green parts of the plant, and photosynthesis takes place in the green parts } \\
\text { of the plant }\end{array}$ & 27.9 & 84.4 \\
\hline
\end{tabular}


The complexity of understanding events related to energy in photosynthesis was examined by cross-analysing the questions 'What type of energy do plants receive from the sun?' and 'Into what type of energy do plants transform sunlight energy?' (Table 8). We found that with pupils and STB the most frequent combination was the correct one: 'Plants receive the light energy from the sun, and transform it into chemical energy' (pupils 29\%, STB 79\%). Pupils' responses indicate considerable confusion in understanding what is happening with energy in photosynthesis. Most pupils know that plants receive light energy, but a problem occurs with understanding energy transformation in photosynthesis. The same proportion of pupils (17\%) answered that light energy is transformed into light energy (thus showing that they do not understand that the process of photosynthesis is about energy transformation), and that light energy is transformed into heat. Most of the other incorrect answers were fairly evenly chosen by both groups, which means that no additional misconceptions were present.

Table 8: Cross-analysis of pupils' and student teachers of biology (STB) responses to explore the complexity of understanding events related to energy in photosynthesis

\begin{tabular}{lcc}
\hline Response & $\begin{array}{c}\text { Pupils } \\
\text { (\%) }\end{array}$ & $\begin{array}{c}\text { STB } \\
(\%)\end{array}$ \\
\hline Plants receive chemical energy from the sun, and transform it into chemical energy & 1.6 & 5.4 \\
Plants receive light energy from the sun, and transform it into movement & 6.0 & 0.5 \\
Plants receive light energy from the sun, and transform it into chemical energy & 29.2 & 78.7 \\
Plants receive light energy from the sun, and transform it into light energy & 16.7 & 3.0 \\
Plants receive light energy from the sun, and transform it into heat & 16.7 & 6.4 \\
Plants receive heat from the sun, and transform it into chemical energy & 4.2 & 4.5 \\
Plants receive heat from the sun, and transform it into chemical energy & 4.2 & 4.5 \\
Plants receive heat from the sun, and transform it into light energy & 6.5 & 0.0 \\
Plants receive heat from the sun, and transform it into heat & 10.2 & 0.5 \\
\hline
\end{tabular}

\section{Development of scientific conceptions about photosynthesis with age}

One of our research questions was to explore the development of pupils' and STB's scientific conceptions of photosynthesis with age. A Kruskal-Wallis $\mathrm{H}$ test showed that there was no statistically significant difference between the STB groups in any of the seven questions that tested the scientific conceptions of photosynthesis $(p>0.05)$. However, differences were significant among primary school pupils. We found statistically significant differences in answers 
to the items 'Which part of the plant contains chlorophyll?' and 'Which substances are products of photosynthesis?' $(p<0.05)$. There were no significant differences regarding the remaining five items $(p>0.05)$.

Primary school pupils had quite diverse conceptions concerning the question 'Which part of the plant contains chlorophyll?' (Figure 1). In the $6^{\text {th }}$ grade, pupils showed the least developed scientific conceptions of where chlorophyll is in the plant. This is not surprising because it could be that this topic may not yet have been addressed in class when surveyed. In the $7^{\text {th }}$ grade, progress had obviously been made concerning the understanding of this concept; $8^{\text {th }}$ grade pupils again showed less knowledge than $7^{\text {th }}$ grade pupils did. Even at the end of $9^{\text {th }}$ grade understanding where chlorophyll is located in plants is worse than in the $7^{\text {th }}$ grade. Despite the problems primary school pupils had with the location of chlorophyll in plants, all grades predominantly chose the completely correct answer that chlorophyll is in the green parts of plants (40\% or more). The sum of correct and partially correct answers show satisfying scientific conceptions (74-90\%) in all four grades.

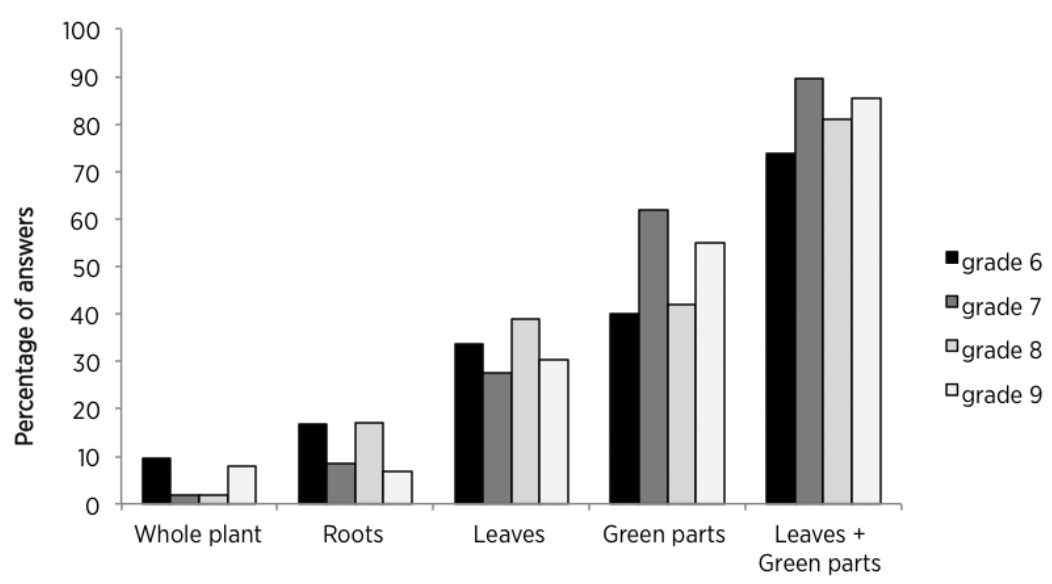

Which part of the plant contains chlorophyll?

Figure 1. Percentage distribution of pupils' responses to the question 'Which part of the plant contains chlorophyll?' according to different grades.

To the question 'Which substances are products of photosynthesis?', pupils in the $6^{\text {th }}$ grade predominantly chose the correct answer (glucose and oxygen; 49\%), and slightly less often the incorrect answer (oxygen and water; 33\%). The majority of pupils in the $7^{\text {th }}, 8^{\text {th }}$, and $9^{\text {th }}$ grades chose the correct answer 
(63-67\%). The second most common response with them was also 'oxygen and water' $(18-21 \%)$. This comparison leads to the conclusion that $6^{\text {th }}$-graders possess more misconceptions about the products of photosynthesis than older pupils do. Among pupils in the $7^{\text {th }}, 8^{\text {th }}$, and $9^{\text {th }}$ grades, there is almost no difference in understanding the products of photosynthesis (Figure 2).

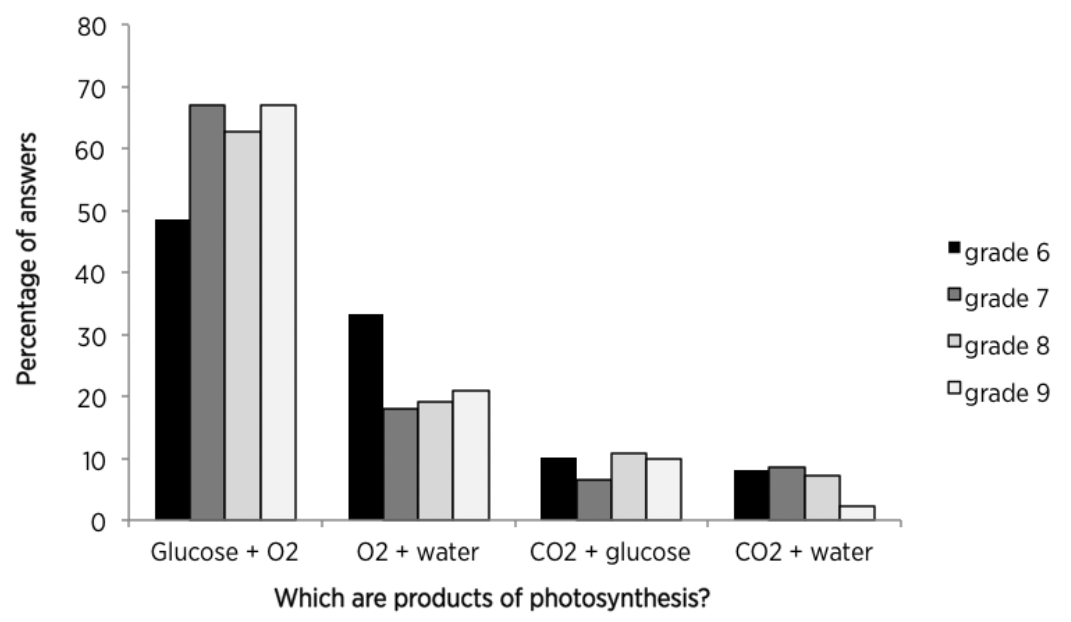

Figure 2. Percentage distribution of pupils' responses of different grades to the question 'Which substances are products of photosynthesis?'

\section{Discussion and conclusions}

In our analysis, we found that primary school pupils and STB differ greatly concerning scientific conceptions of photosynthesis.

Our first research question was focused on the quality of scientific conceptions about photosynthesis. An analysis of the quality of scientific conceptions about photosynthesis held by pupils showed that more pupils think that the main function of photosynthesis is the formation of oxygen, and fewer pupils think that the main function of photosynthesis is the formation of glucose. In contrast, the majority of STB see the formation of glucose as the main function of photosynthesis. In fact, it is difficult to define photosynthesis' 'main' function. From the evolutionary point of view, its primary function is the formation of glucose, while oxygen is a by-product. From the perspective of contemporary aerobic organisms, both products are equally important. In connection with the process of photosynthesis, we found that pupils and STB possess good knowledge of the reactants and products. From these results, we 
concluded that it is relatively easy to learn the basic equation of photosynthesis, which is not necessarily linked to the understanding of this process. A relatively large proportion of pupils' responses that oxygen and water are needed for photosynthesis could be explained by the fact that many people think that photosynthesis is respiration in plants (Driver et al., 1992). Regarding energy in photosynthesis we found that pupils and STB know very well that plants receive light energy from the sun. In contrast, we found that the transformation of energy in photosynthesis presents a problem for pupils, but not for STB. In addition to the chemical energy pupils frequently answered that energy in photosynthesis is transformed into light and heat. The location of chlorophyll and location of photosynthesis in the green parts of the plants is reasonably well understood by STB. In addition to the green parts of the plants, pupils frequently chose particularly the answer 'in the leaf.' This is probably due to many primary school textbooks, in which the process of photosynthesis is shown simplified in a picture of a plant leaf.

Our second research question was focused on the complexity of understanding of scientific conceptions about photosynthesis. How complex the understanding of scientific conceptions about photosynthesis held by pupils and STB is was explored by cross-analysis. In STB knowledge is very complex, since they showed high response consistency. For pupils, we found quite a few problems. Marmaroti and Galanopoulou (2006) stated that it is easier for pupils to identify products than reactants. We did not come to this conclusion, while almost the same percentage of pupils chose the correct products and false reactants or vice-versa. Noteworthy is the proportion of pupils who associate photosynthesis primarily with leaves, but not with all the green parts of the plant. Pupils demonstrated the highest response inconsistency on the topic of the energy transformation in photosynthesis: for the most part they correctly answered that light energy is necessary for photosynthesis, but were confused about the transformation of this energy. They are not even aware of the energy transformation because they answered that light energy enters and exits the reaction. This was also noted by Marmaroti and Galanopoulou (2006) who stated that this means that they do not understand that photosynthesis is a chemical reaction. In the primary school program, more attention should be given to understanding the transformation of energy. This is a key understanding of the functioning of the ecosystems and thus justifies the claim of Arnon (in Barker \& Carr, 1989a) that photosynthesis is the most important biochemical process on Earth.

Our third research question was focused on the development of scientific conceptions about photosynthesis. Analysis of the development of 
scientific conceptions about photosynthesis with age showed that there is very little change among primary school pupils and none among STB. There is, however, a large difference between the two groups. As expected, the scientific conceptions of STB are statistically significantly better than those of the pupils. Progress from the $6^{\text {th }}$ to $9^{\text {th }}$ grade in pupils' scientific conceptions was only found concerning the location of chlorophyll and the products of photosynthesis. The most obvious is the progress from $6^{\text {th }}$ to $7^{\text {th }}$ grade, which indicates the realisation of the objectives of the curriculum of the $6^{\text {th }}$ grade.

We are pleased with the fact that STB mastered the basic subject matter of photosynthesis, but we are less satisfied with the knowledge of pupils, especially at the end of the primary education. Many of the latter will never again learn about photosynthesis in their further education. Inadequate pupil knowledge of photosynthesis is perhaps also a consequence of the fact that teachers are not able to properly present this complex topic in class. Perhaps STB lack pedagogical content knowledge. The study by Rode and Skribe-Dimec (2012), which investigated the understanding of photosynthesis, showed that primary school teachers also have many misconceptions about photosynthesis. This would imply that we must ask ourselves which teaching approaches should be used when this topic is presented to pupils in primary school. There is a variety of approaches that can be used in primary schools so that the pupils would be able to understand this crucial process, such as the constructivist approach (Dolenc Orbanić, Skribe Dimec \& Cencič, 2016), concept mapping (Novak, 1998; Novak \& Gowin, 1984), explicit instruction (Archer \& Hughes, 2011), computer-assisted material (Çepni et al., 2006; Keleş \& Kefeli, 2010), indepth analysis of misconceptions (Amir \& Tamir, 1994), project-based learning (Holubova, 2008), web-based dynamic assessment (Wang, 2010), conceptual change approach (Yenilmez \& Tekkaya, 2006), the $5 \mathrm{E}$ Model (Bybee et al., 2006), etc. In addition, an effective strategy for the professional development of science teachers is investigations in which teachers are not consumers of external knowledge, but co-producers and agents of change in the problems that concern them in their classes (Ritchie, 2008). Da Silva, Mellado, Ruiz \& Porlán (2007) showed that the decisive moment for teachers to change their way of teaching is to confront them with the misconceptions of their students. Therefore, we believe that prospective teachers should have more direct contact with pupils during their study at the university.

In contrast, the question is also whether this topic might be too complex for 11-year-olds (Grade 6, where the current curriculum places it). Biology teachers and curriculum developers should take into account the fact that photosynthesis is challenging and pupils do not find it interesting. However, they 
must understand basic concepts of this process to be able to make informed decisions in life.

Koballa and Glynn (2010) report that a study based on data collected as a part of the TIMSS revealed that attitudes toward science have a strong effect on achievement. They place the importance of attitudes for science learning in the broader context: 'As views of learning become increasingly constructivistic, it is more important than ever, that researchers adopt a comprehensive view of learners that includes affective characteristics' (Koballa \& Glynn, 2010, 93), wherein attitudes are part of the affective domain. Therefore, in future studies we need to focus our attention on pupils' attitudes toward photosynthesis and attempt to determine if there is any correlation between scientific conceptions about photosynthesis held by pupils and biology student teachers and their attitudes toward it.

\section{References}

Amir, R., \& Tamir, P. (1994). In-Depth Analysis of Misconceptions as a Basis for Developing Research-Based Remedial Instruction: The Case of Photosynthesis. The American Biology Teacher, 56(2), 94-100.

Archer, A. L., \& Hughes, C. A. (2011). Explicit instruction. Effective and efficient teaching. New York, London: The Guilford Press.

Barker, M., \& Carr, M. (1989a). Teaching and learning about photosynthesis. Part 1: An assessment in terms of students' prior knowledge. International Journal of Science Education, 11(1), 49-56.

Bybee, R. W., Taylor, J. A., Gardner, A., Van Scotter, P., Carlson Powell, J., \& Westbrook A. (2006). The BSCS ${ }_{5}$ E Instructional Model: Origins and Effectiveness. Biological Sciences Curriculum Study. Colorado Springs. Retrieved 4. 6. 2016 from http://sharepoint.svsd410.org/mshs/ramseyerd/ Science\%20Inquiry\%201\%2020112012/What\%20is\%2oInquiry\%2oSciecne\%2o(long\%2oversion).pdf. Çepni, S., Taș, E., \& Köse, S. (2006). The effects of computer-assisted material on students' cognitive levels, misconceptions and attitudes towards science. Computer \& Education, 46(2), 192-205. da Silva, C., Mellado, V., Ruiz, C., \& Porlán, R. (2007). Evolution of the conceptions of a secondary education biology teacher: longitudinal analysis using cognitive maps. Science Education, 91(3), 461-91.

Deshmukh, N. D. (2015). Why Do School Students Have Misconceptions About Life Processes? In E. Gnanamalar Sarojini Daniel (Ed.), Biology Education and Research in a Changing Planet (pp. 31-43). Singapore: Springer Science + Business Media.

Dolenc Orbanić, N., Skribe Dimec, D., \& Cencič, M. (2016). The effectiveness of a constructivist teaching model on students' understanding of photosynthesis. Journal of Baltic science education, 15(6), 575-587.

Domingos-Grilo, P., Reis-Grilo, C., Ruiz, C., \& Mellado, V. (2012). An action-research programme 
with secondary education teachers on teaching and learning photosynthesis. Journal of Biological

Education, 46(2), 72-80.

Driver, R. et al. (1992). Nutrition. Leeds national curriculum science support project. Leeds: City

Council and the University of Leeds.

Holubova, R. (2008). Effective teaching methods - project-based learning in physics. US-China

Education Review, 5(12), 27-36.

Keleş, E., \& Kefeli, P. (2010). Determination of student misconceptions in 'photosynthesis and respiration' unit and correcting them with the help of CAI material. Procedia Social and Behavioral Sciences, 2(2), 3111-3118.

Koballa, T. R., \& Glynn, S. M. (2010). Attitudinal and Motivational Constructs in Science Learning. In S. K. Abell \& N. G. Lederman (Ed.), Handbook of Research on Science Education (pp. 75-102). New York: Routledge.

Kolar, M., Krnel, D., \& Velkavrh, A. (2011). Spoznavanje okolja. Učni načrt [Getting to know the environment. National curriculum]. Ljubljana: Ministrstvo za šolstvo in šport, Zavod RS za šolstvo. Leeds national curriculum science support project (1992). Leeds: City Council and the University of Leeds.

Marmaroti, P., \& Galanopoulou, D. (2006). Pupils' Understanding of Photosynthesis: A questionnaire for the simultaneous assessment of all aspects. International Journal of Science Education, 28(4), 383-403.

National Research Council (1996). National Science Education Standards. Washington: National Academy Press.

Next generation science standards (2013). Retrieved 4. 6. 2017 from http://www.nextgenscience.org/ dci-arrangement/ms-ls1-molecules-organisms-structures-and-processes.

Novak, J. D. (1998). Learning, Creating, and Using Knowledge: Concept maps as facilitative tools for schools and corporations. Mahwah, N. J.: Lawrence Erlbaum \& Assoc.

Novak, J. D., \& Gowin, D. B. (1984). Learning How to Learn. Cambridge, New York: Cambridge University Press.

Ritchie, S. M. (2008). Editorial: The next phase in scholarship and innovative research in science education. Research in Science Education, 38(1), 1-2.

Rode, S., \& Skribe Dimec, D. (2012). Pojmovanje fotosinteze [Understanding of photosynthesis]. Naravoslovna solnica, 16(3), 4-7.

Skvarč, M., Glažar, S. A., Marhl, M., Skribe Dimec, D., Zupan, A., \& Cvahte, M. (2011). Učni načrt. Program osnovna šola. Naravoslovje [National curriculum. Programme of basic education. Science.]. Ljubljana: Ministrstvo za šolstvo in šport, Zavod RS za šolstvo.

Taber, K. S. (2011). Constructivism as educational theory: Contingency in learning, and optimally guided instruction. In J. Hassaskhah (Ed.), Educational Theory (pp. 39-61). New York: Nova. Vilhar, B., Zupančič, G., Gilčvert Berdnik, D., Vičar, M., Zupan, A., \& Sobočan, V. (2011). Učni načrt. Program osnovna šola. Biologija [National curriculum. Programme of basic education. Biology]. Ljubljana: Ministrstvo za šolstvo in šport, Zavod RS za šolstvo. 
Vodopivec, I., Papotnik, A., Gostinčar Blagotinšek, A., Skribe Dimec, D., \& Balon, A. (2011). Naravoslovje in tehnika. Učni načrt [Science and technics. National curriculum]. Ljubljana: Ministrstvo RS za šolstvo in šport, Zavod RS za šolstvo.

Wang, T. H. (2010). Web-based dynamic assessment: Taking assessment as teaching and learning strategy for improving student's e-Learning effectiveness. Computer \& Education, 54(4), 1157-1166. Yenilmez, A., \& Tekkaya, C. (2006). Enhancing students' understanding of photosynthesis and respiration in plant through conceptual change approach. Journal of Science Education and Technology, 15(1), 81-87.

\section{Biographical note}

Darja Skribe Dimec, PhD, is an Assistant Professor for Didactics of Primary Science at the Faculty of Education, University of Ljubljana. She has $\mathrm{PhD}$ in biology education and diploma in Montessori pedagogy as well. Her work focuses mainly on assessment, constructivist approach in science classes, children with special needs, outdoor education and education for sustainable development. She is the author of scientific monograph "S preverjanjem znanja do naravoslovne pismenosti [From assessment to science literacy]" (Ljubljana, DZS, 2007). She is the main author of several textbooks as well as successful and awarded educational resources in e-learning formats. She is also a member of a group that developed national curriculum for primary science.

Jelka Strgar, PhD, is Associate Professor of Biology Education at the Biotechnical Faculty, Department of Biology, University of Ljubljana, Slovenia. Her work focuses on didactics of biology. In connection to that she deals with the role of written materials in learning and teaching, as well as with evaluating of knowledge. She is currently the head of national commission for testing knowledge in biology at the end of primary education. 